\title{
Changes in enzymatic activity, accumulation of proteins and softening of persimmon (Diospyros kaki Thunb.) flesh as a function of pre-cooling acclimatization
}

\author{
Edson Luiz de Souza ${ }^{\mathrm{a}, *}$, André Luiz Kulkamp de Souza ${ }^{\mathrm{b}}$, Aline Tiecher ${ }^{\mathrm{b}}$, César Luis Girardi ${ }^{\mathrm{c}}$, \\ Leonardo Nora $^{\mathrm{b}}$, Jorge Adolfo da Silva ${ }^{\mathrm{b}}$, Luiz Carlos Argenta ${ }^{\mathrm{d}}$, Cesar Valmor Rombaldi ${ }^{\mathrm{b}}$ \\ a Epagri, P.O.B 21, CEP 89560-000, Videira-SC, Brazil \\ ${ }^{\mathrm{b}}$ Universidade Federal de Pelotas (UFPel), Departamento de Ciência e Tecnologia Agroindustrial (DCTA), P.O.B 354, CEP 96010-900, Pelotas-RS, Brazil \\ c Embrapa Uva e Vinho, P.O.B 130, CEP 95.700-000, Bento Gonçalves-RS, Brazil \\ d Epagri, P.O.B 591, CEP 89500-000, Caçador-SC, Brazil
}

\section{A R T I C L E I N F O}

\section{Article history:}

Received 6 August 2010

Received in revised form

23 September 2010

Accepted 29 September 2010

\section{Keywords:}

Cell wall disassembling

Pectin methylesterase (PME)

Polygalacturonase (PG)

Expansins

Heat shock proteins

\begin{abstract}
A B S T R A C T
One of the major causes of 'Fuyu' persimmon loss after cold storage (CS) is the breakdown of its flesh, which results in the production of a translucent fruit (a water-soaked fruit). It is believed that the cause of this disturbance is linked to disorganization of the cytoskelet and endomembrane system, which changes the synthesis and transport of proteins and metabolites, resulting in incomplete ripening. To test this hypothesis, 'Fuyu' persimmon was subjected to three different postharvest treatments (T): Control harvested and kept at $23 \pm 3{ }^{\circ} \mathrm{C}$ and relative humidity (RH) of $85 \pm 5 \%$ (room temperature, RT) for 12 days, T1 - harvested and kept under cold storage (CS) $\left(1 \pm 1^{\circ} \mathrm{C}\right.$ and RH of $\left.85 \pm 5 \%\right)$ for 30 days followed by RT storage for 2 days, T2 - kept under RT for 2 days (acclimatization) followed by CS for 30 days. Control and T2 resulted in fruit with decreased flesh firmness (FF), and increased soluble solids (SS) and ascorbic acid (AA) contents. In these fruit the activity of endo-1,4-ß-glucanase (endo-1,4- $ß$-gluc), pectin methylesterase (PME), polygalacturonase (PG) and $ß$-galactosidase ( $ß$-gal) increased. T1 resulted in translucent fruit with decreased FF, without any enzymatic activity changes, probably due to the physical disruption of the cytoskeleton. Further, there was an increased content of proteins corresponding to expansins in fruit kept under Control and T2 conditions, which suggests that these conditions do contribute to the synthesis and/or transport of proteins involved in the process of solubilization of the cell wall. In these fruit, there was also a major accumulation of gene transcripts corresponding to heat shock proteins (HSPs) of organelles related to endomembrane, which suggests participation of these genes in the prevention of damage caused by cold conditions. These data proved the hypotheses that acclimatization contributes to the expression of HSPs, and synthesis and transportat of proteins involved in the solubilization of the cell wall. The expression of these genes results in the normal ripening of the persimmon, as confirmed by the evolution of ethylene production.
\end{abstract}

(c) 2010 Elsevier B.V. All rights reserved.

\section{Introduction}

Among the methods used to maximize the storage period of 'Fuyu' persimmon, cold storage (CS), storage in a modified atmosphere (MA) and storage under a controlled atmosphere (CA) have been suggested. With $\mathrm{CS}$ at $0-1{ }^{\circ} \mathrm{C}$, damage caused by cold is often observed and is characterized by the breakdown of flesh 1-2 days after its removal from the cold chamber (George et al., 1997; Krammes et al., 2006).

\footnotetext{
* Corresponding author. Tel.: +55 49 35660054; fax: +55 4935660391. E-mail addresses: edsonluiz@epagri.sc.gov.br, edsonluizdesouza@gmail.com (E.L.d. Souza).
}

During persimmon ripening, softening is caused by the activity of the hydrolytic enzymes of the cell wall and by proteins that facilitate these activities such as expansins (Nakano et al., 2003). However, there is little information regarding this process or regarding the enzymatic behavior after CS or after acclimatization followed by CS. In other species, enzymes that are more involved with the metabolism of the cell wall, and thus responsible for the solubility of its macromolecules, include endo1,4-ß-glucanase (endo-1,4-ß-gluc), pectin methylesterase (PME), polygalacturonase (PG) and ß-galactosidase ( $ß$-gal) (Brummell, 2006; Nakamura et al., 2003). Moreover, it is known that adequate ripening is the result of the evolution of ethylene production and the maintenance of the endomembrane system, which is responsible for the transportation of proteins including ones involved in 
cell wall solubilization (Rose et al., 1998). Several reports describe that pre-storage treatments such as the use of growth regulators (Krammes et al., 2006; Pegoraro et al., 2010) or physical treatments (Boston et al., 1996; Sabehat et al., 1998; Sun et al., 2010) can contribute to the preservation of cellular homeostasis and prevent damage by cold storage.

The goal of this study was to identify the mechanisms involved in the sudden loss of flesh firmness (FF) soon after removing the fruit from the cold and to verify the effect of acclimatization prior to CS in the prevention of chilling injury. Acclimatization is the condition that fruit are conditioned at temperature lower or higher than room temperature (RT), before CS. From exploratory studies in with several temperature combinations $\left(15-50^{\circ} \mathrm{C}\right.$ in warmed water or air) and multiple time periods (from 2 min to 4 days) were tested we found that the optimal acclimatization for prevention of chilling injury in persimmon fruit 'Fuyu' was $23 \pm 3^{\circ} \mathrm{C}$ for 2 days. In this case the acclimatization corresponded to fruit conditioning at RT.

To achieve this, we both related enzymatic activities with FF loss and evaluated the content of ascorbic acid (AA), which are indicators of the evolution of the ripening processes of fruit that contain significant concentrations of pectins (Gomez and Lajolo, 2008). During normal ripening of fruit, it is expected that solubilization of pectins will cause an increase in AA (Barata-Soares et al., 2004; Gomez and Lajolo, 2008). Moreover, it is believed that delaying CS of persimmon could stimulate activity of HSPs genes (Sabehat et al., 1998; Sun et al., 2010), thus protecting the synthesis and transport of proteins and organelle homeostasis, which would result in adequate ripening.

\section{Materials and methods}

\subsection{Plant material and experimental design}

Persimmon (Diospyros kaki, cv. Fuyu) fruit from a commercial orchard located in the municipality of Canguçu/RS, South of Brazil, were harvested in 2010 when the epicarp were orange in color. The average values for $\mathrm{L}^{*}, \mathrm{a}^{*}$ and $\mathrm{b}^{*}$ were $56.3,34.7$ and 49.1 , respectively. The Hue angle was 54.7 , and the SS content was $15.2 \%$. The FF average was 82.6 Newton (N), and the average fruit weight was $256.5 \mathrm{~g}$. Prior to treatment application, the fruit were randomly divided into 42 experimental units with 10 persimmons in each group. Then, each treatment was applied to a random fruit, and all experiments were repeated in triplicate. Persimmons were stored under the following conditions:

Control: $23 \pm 3^{\circ} \mathrm{C}$ and $\mathrm{RH}$ of $85 \pm 5 \%$ (room temperature, RT) for 12 days;

T1: $1 \pm 1^{\circ} \mathrm{C}$ and $\mathrm{RH}$ of $85 \pm 5 \%$ (cold storage, CS) for 30 days, followed by storage at $23 \pm 3{ }^{\circ} \mathrm{C}$ and $\mathrm{RH}$ of $85 \pm 5 \%$ for 2 days;

T2: $23 \pm 3{ }^{\circ} \mathrm{C}$ and $\mathrm{RH}$ of $85 \pm 5 \%$ for 2 days (acclimatization) followed by the same conditions described for T1 for 30 days.

For storage under Control, the first sample collection was performed soon after harvest, and thereafter at intervals of 2 days until the twelfth day of storage. A total of seven additional sample collections were made. On the other hand, T1 and T2 treated fruit were analyzed after 30 days under $\mathrm{CS}$ and then at $12 \mathrm{~h}$ interval for 2 days. The FF, SS, AA content, enzymatic activities of endo-1,4ß-gluc, PME, PG and ß-gal and the immunodetection of expansins were measured. The accumulation of transcripts of the genes corresponding to expansins (Exp3) and HSPs were also evaluated, via RT-qPCR. There were multiple HSP genes examined, associated with different regions of the cell: cytosol (Ps-CI sHSP1 and Ps-CI sHSP2), lumen of the endoplasmic reticulum (HSP40-1er), chloro- plasts (HSP70 chl and HSP17.8 chl) and mitochondria (HSP60 mit and HSP26.5 mit). The RT-qPCR of the Control was analyzed at 0 , 24,48 and $72 \mathrm{~h}$ after harvesting. The Exp3 was also evaluated. The RT-qPCR results of the T1 and T2 samples were analyzed 0, 12, 24, 36 and $48 \mathrm{~h}$ after removal from the cold chamber. Variance analysis was performed on the data, and the least significant difference (LSD) and Tukey test $(p<0.05)$ among treatments were determined using the Winstat program (Machado and Conceição, 2003).

\subsection{Physico-chemical analysis}

The flesh firmness (FF) was measured using a manual penetrometer, with a tip of $11 \mathrm{~mm}$, and the results were reported in Newtons (N). The content of soluble solids (SS) was determined by refractometry, with results expressed as percentages $(\mathrm{m} / \mathrm{m})$. The content of ascorbic acid (AA) was determined using the extraction method of Vinci et al. (1995) in which $3 \mathrm{~g}$ of fruit is added to $5 \mathrm{~mL}$ of metaphosphoric acid at $4.5 \%(\mathrm{v} / \mathrm{v})$ for $1 \mathrm{~h}$ in a light-proofed flask. Then, the samples were filled to a volume of $10 \mathrm{~mL}$ with ultra-pure water and homogenized. After homogenization, two filtrations with Whatman no. 3 paper were performed. The filtrate was centrifuged at $10,000 \times \mathrm{g}$ for $10 \min$ at $4{ }^{\circ} \mathrm{C}$, and the supernatant was used for analysis in a Shimadzu chromatograph equipped with the following modules: solvent mixer LC-10AT $\mathrm{VP}_{\mathrm{VP}}$, degasser FCV$10 A_{V P}$, pump reodine DGU- $14_{A}$, control system SCL- $10^{\mathrm{A}} \mathrm{VP}$, column oven CTO-10AS $\mathrm{VP}$ and autosampler SIL-10AF. A reverse phase analytical separation column, Nova-Pak $\mathrm{C}_{18}(3.9 \mathrm{~cm} \times 150 \mathrm{~mm} \times 4 \mu \mathrm{m})$, was used. The mobile phase consisted of two solvents: (A) $0.1 \%$ acetic acid solution and (B) methanol. A total of $10 \mu \mathrm{L}$ of sample was injected at a rate of $0.8 \mathrm{~mL} \mathrm{~min}^{-1}$ at a column temperature that was maintained between 25 and $40^{\circ} \mathrm{C}$. The elution time of the sample was $30 \mathrm{~min}$. Compound identification was obtained from the absorption spectrum in the UV-visible using a model SPD- $10 \mathrm{AV}$ VP at the wavelength of $254 \mathrm{~nm}$. The recovery rate of the method was determined to be $93 \%$, and the data were acquired and processed using the software Class-VP. Results were expressed as mg of AA per $100 \mathrm{~g}$ of fresh material.

\subsection{Enzymatic activities}

To determine enzymatic activities, methods based on the procedures previously calibrated for strawberries (Martínez and Civello, 2008) and peaches (Girardi et al., 2005) were used with slight modifications. In these studies, the flesh was frozen in liquid nitrogen and stored at either $-85^{\circ} \mathrm{C}$ or $-20^{\circ} \mathrm{C}$ prior to analysis. For persimmon, it was found that using the exact procedure of those previous studies led to poor reproducibility in the enzymatic activities measurements. Better results were obtained by adding the extraction buffers ( $3 \mathrm{mLg}^{-1}$ of flesh) prior to storage of samples at $-85^{\circ} \mathrm{C}$. Good separation of the supernatant and high reproducibility were obtained using this modification.

The determination of the enzymatic activities of endo-1,4-ßgluc was performed with a sample of frozen persimmons and its extraction buffer containing $50 \mathrm{mM}$ sodium acetate and $10 \mathrm{~g} \mathrm{~L}^{-1}$ polyvinylpolypyrrolidone (PVPP) at pH 6.0 (buffer A). After disintegration of the frozen flesh in the presence of the buffer at a volume ratio of $1: 3$, the suspension was centrifuged at $20,000 \times g$ at $4{ }^{\circ} \mathrm{C}$ for $30 \mathrm{~min}$ and the supernatant was discarded. The precipitate was resuspended in $15 \mathrm{~mL}$ of buffer $\mathrm{A}$, homogenized for $30 \mathrm{~min}$ and centrifuged again. The precipitate from this stage was resuspended in $15 \mathrm{~mL}$ of buffer containing $50 \mathrm{mM}$ sodium acetate, $1 \mathrm{M}$ of $\mathrm{NaCl}$ and $10 \mathrm{~g} \mathrm{~L}^{-1}$ PVPP at $\mathrm{pH} 6.0$ (buffer B) and kept under agitation at $4{ }^{\circ} \mathrm{C}$ for $1 \mathrm{~h}$. After this period, the material was centrifuged at $20,000 \times \mathrm{g}$ at $4{ }^{\circ} \mathrm{C}$ for $1 \mathrm{~h}$. For each analysis repetition of the enzyme assay, $1.5 \mathrm{~mL}$ of supernatant was added to $0.5 \mathrm{~mL}$ of buffer B with $0.5 \%(\mathrm{~m} / \mathrm{v})$ of carboxymethylcellulose. The mixture was then incubated at $30^{\circ} \mathrm{C}$, 
and determinations of enzymatic activities were made regularly during the first $12 \mathrm{~h}$ of incubation. After the first $12 \mathrm{~h}$, readings were taken every $2 \mathrm{~h}$ for $24 \mathrm{~h}$. Reaction mixtures, without either the substrate or the enzyme extract were analyzed as negative controls. The results were expressed in nanomoles of glucose produced per hour per gram of protein in the enzyme extract.

The PG activity was measured in the enzyme extract obtained by centrifuging at $20,000 \times g$ for $30 \mathrm{~min}$ the crushed and frozen flesh samples in the presence of buffer $A$. The reaction was performed in a final volume of $4 \mathrm{~mL}$, with $2 \mathrm{~mL}$ of the enzyme extract (supernatant) and $2 \mathrm{~mL}$ of a solution composed of $50 \mathrm{mM}$ sodium acetate at $\mathrm{pH} 6.0$ with $0.3 \%(\mathrm{~m} / \mathrm{v})$ polygalacturonic acid. The reaction was conducted at $30^{\circ} \mathrm{C}$ over $24 \mathrm{~h}$ with two samples of $300 \mu \mathrm{L}$; one reacted for $12 \mathrm{~h}$ and the other reacted for $24 \mathrm{~h}$. The quantity of galacturonic acid released was measured by reaction with 2 -cyano-acetamide, and the activity was expressed in nanomoles of this molecule per hour per gram of protein in the enzyme extract.

The PME activity was determined according to the previously optimized procedure for peach (Girardi et al., 2005).

To determine the ß-gal enzyme activity, the samples were frozen with buffer $\mathrm{B}$, crushed, thawed at $4{ }^{\circ} \mathrm{C}$ and centrifuged at $20,000 \times g$ for $30 \mathrm{~min}$. The activity was measured in a reaction buffer containing $50 \mathrm{mM}$ sodium acetate at $\mathrm{pH} 4.5,2 \mathrm{~mL}$ of enzyme extract (supernatant) and $5 \mathrm{mM} p$-nitrophenyl-ß-D-galactopyranoside in a final volume of $4 \mathrm{~mL}$. The reaction was incubated at $30^{\circ} \mathrm{C}$ and $300 \mu \mathrm{L}$ aliquots were collected every $10 \mathrm{~min}$ for $1 \mathrm{~h}$. The activity was determined in a solution with $400 \mathrm{mM} \mathrm{Na} \mathrm{CO}_{3}$. The activity was expressed as nanomoles of $p$-nitrophenol per minute per gram of protein in the enzyme extract.

\subsection{Ethylene production}

The production of ethylene was examined following the procedures described by Pegoraro et al. (2010), and the results were expressed in $\mathrm{nLg}^{-1} \mathrm{~h}^{-1}$.

\subsection{Western blot}

For immunodetection of expansins, Western blotting was performed. The total protein extract from persimmon flesh was extracted using $1 \mathrm{~g}$ of flesh and $1 \mathrm{~mL}$ of Laemmli $(2 \times)$ buffer. Evaluations were performed five times for all treatments. After $10 \mathrm{~min}$ of homogenization, the material was heated to $90^{\circ} \mathrm{C}$ for $5 \mathrm{~min}$ and then centrifuged at $14,000 \times g$ for $30 \mathrm{~min}$. The supernatant was used to perform SDS-PAGE electrophoresis. Once migration was complete, the proteins were transferred to a nitrocellulose membrane (Sigma) using a Bio-Rad apparatus. The membrane was blocked with TTBS containing $2 \%$ (m/v) skim milk powder. Then, the membrane was incubated for $2 \mathrm{~h}$ with a mouse polyclonal anti-expansin antibody (Pegoraro et al., 2010) that was diluted 1:2500 in TTBS. After three washes with TTBS, the membrane was incubated with goat anti-mouse antibody that was diluted 1:50,000 in TTBS, and staining was performed with the ECL advanced $k^{t^{\circledR}}{ }^{\circledR}$. In each lane, $20 \mu \mathrm{g}$ of total protein was run.

\subsection{Quantitative Real-Time PCR (RT-qPCR)}

RNA was extracted from flesh of persimmon following the protocol described for PureLinK ${ }^{\mathrm{TM}}$ reagent (Plant RNA Reagent-Invitrogen ${ }^{\mathrm{TM}}$ ). Total RNA was treated with DNAse I-Invitrogen ${ }^{\mathrm{TM}}$ and each sample was reverse transcribed into cDNAs using the commercial kit SuperScript First-Strand System for RT-PCR (Invitrogen ${ }^{\mathrm{TM}}$ ). The quantity and quality of the RNA and cDNA was assessed spectroscopically, by PCR and electrophoresis in agarose gel.
Genes from peach, tomato, plum and arabidopsis putatively encoding for proteins involved in cell wall metabolism (Exp3) and heat shock proteins (Ps-CI sHSP1, Ps-CI sHSP2, HSP40-1er, HSP70 chl, HSP17.8 chl, HSP60 mit e HSP26.5 mit) were selected based on previous work that showed an association between these metabolic functions and woolliness (Deacon, 2009; González-Agüero et al., 2008; Iwata et al., 2008; Mueller et al., 2008; Pratt and Toft, 2003; Su and Li, 2008; Trainotti et al., 2006, 2003). Gene-specific primers were designed from sequences deposited in the GeneBank (Benson et al., 2005) using Vector NTI Advance ${ }^{\mathrm{TM}} 10$ (Invitrogen, 2005). The criteria used for primer selection consisted of: amplicon size, between 100 and $150 \mathrm{bp}$; CG content, between $40 \%$ and 60\%; $3^{\prime}$ ends with less than two $C$ and $G$ bases in the last five nucleotides; and melting temperature ranging from 60 to $65^{\circ} \mathrm{C}$; according to Applied Biosystems ${ }^{\circledR}$ recommendations. The sizes of amplification products and their specificity were tested in agarose gels $(2 \%, \mathrm{w} / \mathrm{v})$ and by sequencing prior to RT-qPCR. Melting curves were evaluated and only primers giving single peaks were used. RT-qPCR was performed with a 7500 Real-Time PCR System (Applied Biosystems ${ }^{\circledR}$ ) using SYBR ${ }^{\circledR}$ Green. The amplification reaction was carried out in a total volume of $25 \mu \mathrm{L}$, containing $2 \mu \mathrm{M}$ of each primer, $12.5 \mu \mathrm{L}$ of PCR Master Mix SYBR ${ }^{\circledR}$ Green, $1 \mu \mathrm{L}$ of cDNA (diluted 5-fold) and water to make up the final volume. Samples were loaded in 96 well optic plates (Applied Biosystems ${ }^{\circledR}$ ) and covered with optic adhesives (Applied Biosystems ${ }^{\circledR}$ ). Thermal cycle conditions were as follows: denaturing at $50^{\circ} \mathrm{C}$ for $2 \mathrm{~min}$ and $95^{\circ} \mathrm{C}$ for $10 \mathrm{~min}$, followed by 40 three-step cycles $\left(95^{\circ} \mathrm{C}\right.$ for $30 \mathrm{~s}, 57^{\circ} \mathrm{C}$ for $1 \mathrm{~min}$ and $72{ }^{\circ} \mathrm{C}$ for $1 \mathrm{~min}$ ) and final extension at $72^{\circ} \mathrm{C}$ for $5 \mathrm{~min}$. Relative quantification of each single gene expression was performed using the comparative threshold cycle method, as described by Livak and Schmittgen (2001). For each cDNA, 18S was used as a reference gene to quantify cDNA abundance (at the same dilution as mentioned above). Threshold cycle (CT) was calculated based on the PCR exponential reaction obtained from the relative expression content (REL) formula, $\mathrm{REL}=2^{-\Delta \Delta C \mathrm{C}}$. Results were expressed as mRNA abundance in a color diagram using the Multi Experiment Viewer (TIGR MeV) software (Saeed et al., 2003). mRNA abundance of each gene from Control fruit at $0 \mathrm{~h}$ served as the baseline for determining relative RNA content.

\section{Results}

'Fuyu' persimmon harvest and kept either at room temperature (Control), under cold storage (T1) and under cold storage after acclimatization (T2) was distinctively affected in terms of flesh firmness (FF), soluble solids (SS), ascorbic acid (AA), ethylene production, enzyme activity, mRNA and protein accumulation.

FF was $82.6 \mathrm{~N}$ at harvest (Control), $84 \mathrm{~N}$ after CS (T1) and $67 \mathrm{~N}$ after 2 days of acclimatization fallowed by 30 days under CS (T2). The lower FF observed in T2 fruits immediately after CS could be explained by evaluative of ripening during acclimatization (2 days at $23 \pm 3^{\circ} \mathrm{C}$ ) before $\mathrm{CS}$.

We observed that FF reduction occurred as expected in fruit from Control that corresponds to fruit harvest and kept at room temperature without CS (Fig. 1A). On the other hand, fruit from T1 and T2 (evaluated after 30 days under CS), showed a quick reduction of FF, but at lower intensity in T2 fruit. However, what stands out is that the reduction in the FF under either Control, T1 or T2 was followed by an increase in the content of SS (Fig. 1B) and AA (Fig. 1C). Interestingly, the content of SS and AA increased to a lesser extend in persimmons that were subjected to $\mathrm{T} 1$, indicating an abnormal ripening process.

Persimmon under Control and T2 ripened normally as characterized by the evolution of ethylene production (Fig. 1D) and resulted 


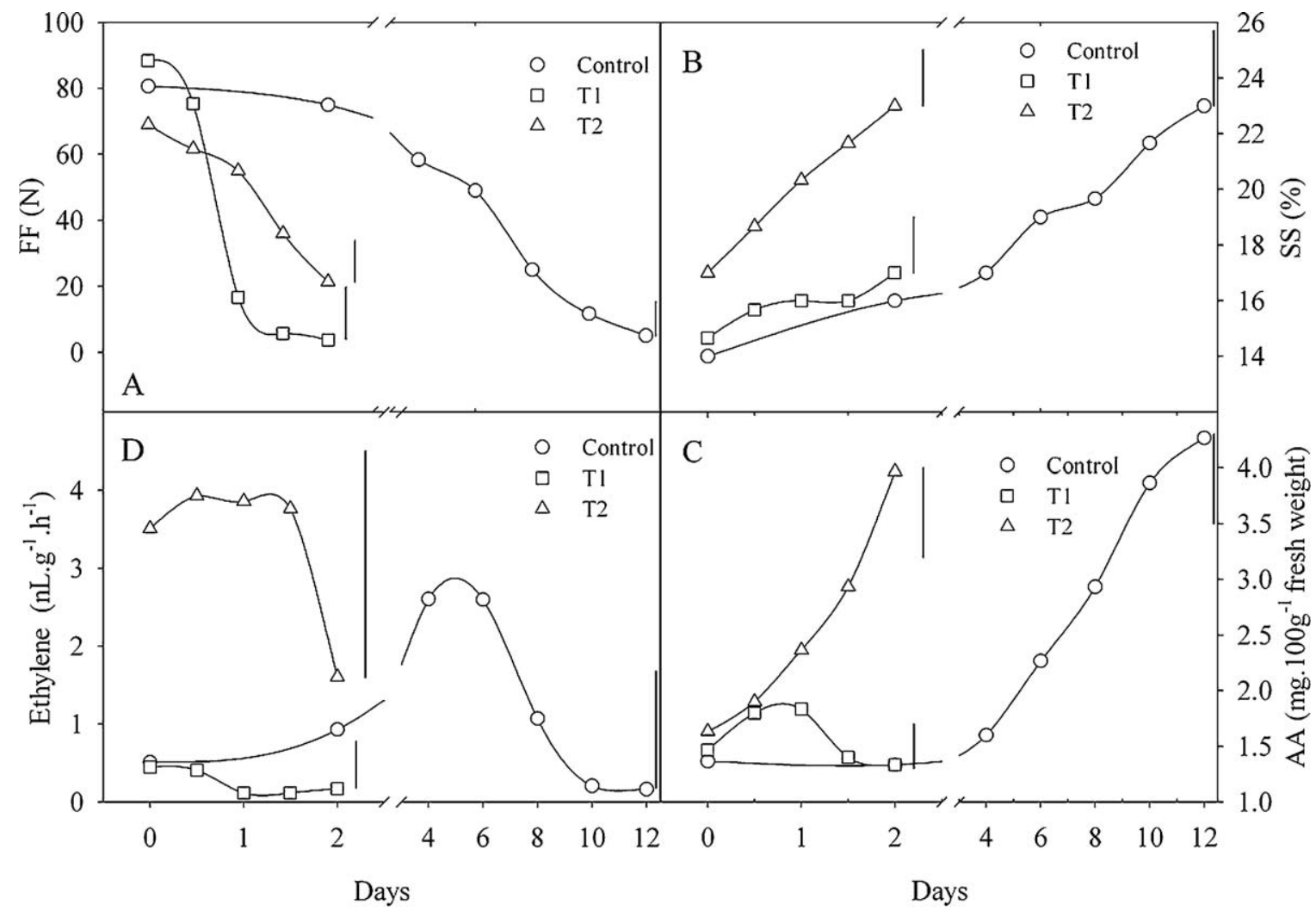

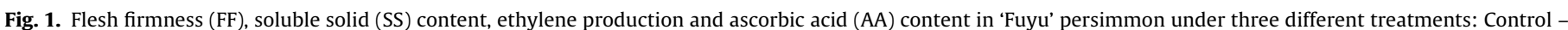

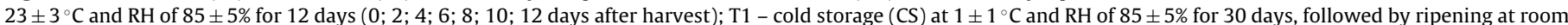

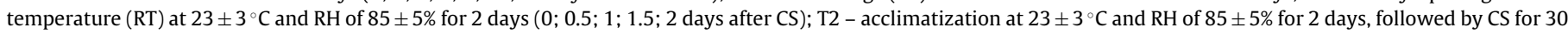
days and ripening at RT for 2 days $(0 ; 0.5 ; 1 ; 1.5 ; 2$ days after CS). Vertical bars indicate the value of MSD for time effect in each treatment ( $p<0.05)$.

in an elevation in enzymatic activity (endo-1,4- $\beta$-gluc, PME, PG and $\beta$-gal), followed by an enzymatic activity stabilization or reduction (Fig. 2). In persimmon under T1, the mentioned enzymatic activities and ethylene production were generally smaller.

The increases in activity of the enzyme endo-1,4- $\beta$-gluc during fruit ripening in persimmon under Control and T2 groups are consistent with the reductions in the FF. In our experiment, it was noted that during the normal softening of persimmon occurred prior to CS, during acclimatization, there were higher expression content of expansins (Fig. 3) as well as endo-1,4- $\beta$-gluc (Fig. 2A). With regard to the two most cited enzymes that are responsible for demethylation and hydrolysis of pectin in fruit (PMEs and PGs), their behaviors were similar to endo-1,4- $\beta$-gluc (Fig. 2). We observed that the fruit kept under Control showed an increase in the activities of PME and PG during a period in which there was also a large reduction of FF. This pattern also occurred in fruit subjected to the T2. In the fruit subjected to T1, although there was a significant loss of FF, the loss was not correlated to the enzymatic activity, which indicates that the softening of the fruit was not dependent on these enzymes. The activity of the enzyme $\beta$-gal was increased in the first 4 days of storage under RT (Control), followed by a period of stabilization and finally ending with a decreasing trend at 6 days (Fig. 2D). Similarly to the others enzymes studied in this work, the $\beta$-gal showed higher activity in fruit Control and $\mathrm{T} 2$.

Accumulation of expansins was higher in the fruit subjected to Control and T2 than in the fruit subjected to T1 (Fig. 3). In 'Fuyu' persimmon the accumulation of HSPs transcripts was higher in the fruit subjected to T2 than in the fruit subjected to Control and T1 (Fig. 4).

\section{Discussion}

It is widely known that one of the main limitations of CS is the softening of the fruit, characterized by flesh breakdown, after their removal from a cold chamber. This flesh breakdown is probably due to the physical disruption of the cytoskeleton and the endomembrane system (Krammes et al., 2006). We successfully alleviated the fruit softening problem by delaying CS after harvest (T2). In this treatment fruit were kept at $23 \pm 3^{\circ} \mathrm{C}$ for 2 days before CS. The flesh firmness of the fruit decreased approximately $84 \mathrm{~N}$ when kept in CS (T1) as compared with only $47 \mathrm{~N}$ when the fruit were first acclimatized (T2). A similar result has already been shown for the same cultivar in New Zealand by MacRae (1987). However the research (Sun et al., 2010) that uses the term acclimatization referred to temperatures between 5 and $15^{\circ} \mathrm{C}$ instead $23 \pm 3^{\circ} \mathrm{C}$ used here.

The increase in the content of AA could be associated with a solubilization of cell wall components, which might cause a FF reduction and/or the conversion of part of the galacturonic acids to AA. According to Gomez and Lajolo (2008), the production of AA in the fruit originates from two sources; synthesis and accumulation during growth as a result of photosynthetic equilibrium and the bioconversion of molecules during ripening. This latter source may be particularly appropriate to our hypothesis regarding the potential solubilization of the cell wall, which is likely to occur when the harvested persimmons were stored at RT (Control) or submitted to acclimatization prior to cold storage (T1). In the fruit that were submitted to CS, the abrupt loss of FF during the first day after CS removal was not associated with any large variations in the content of SS and AA, which suggests that the decreased FF is likely caused by physical disruption by the action of low temperatures, 


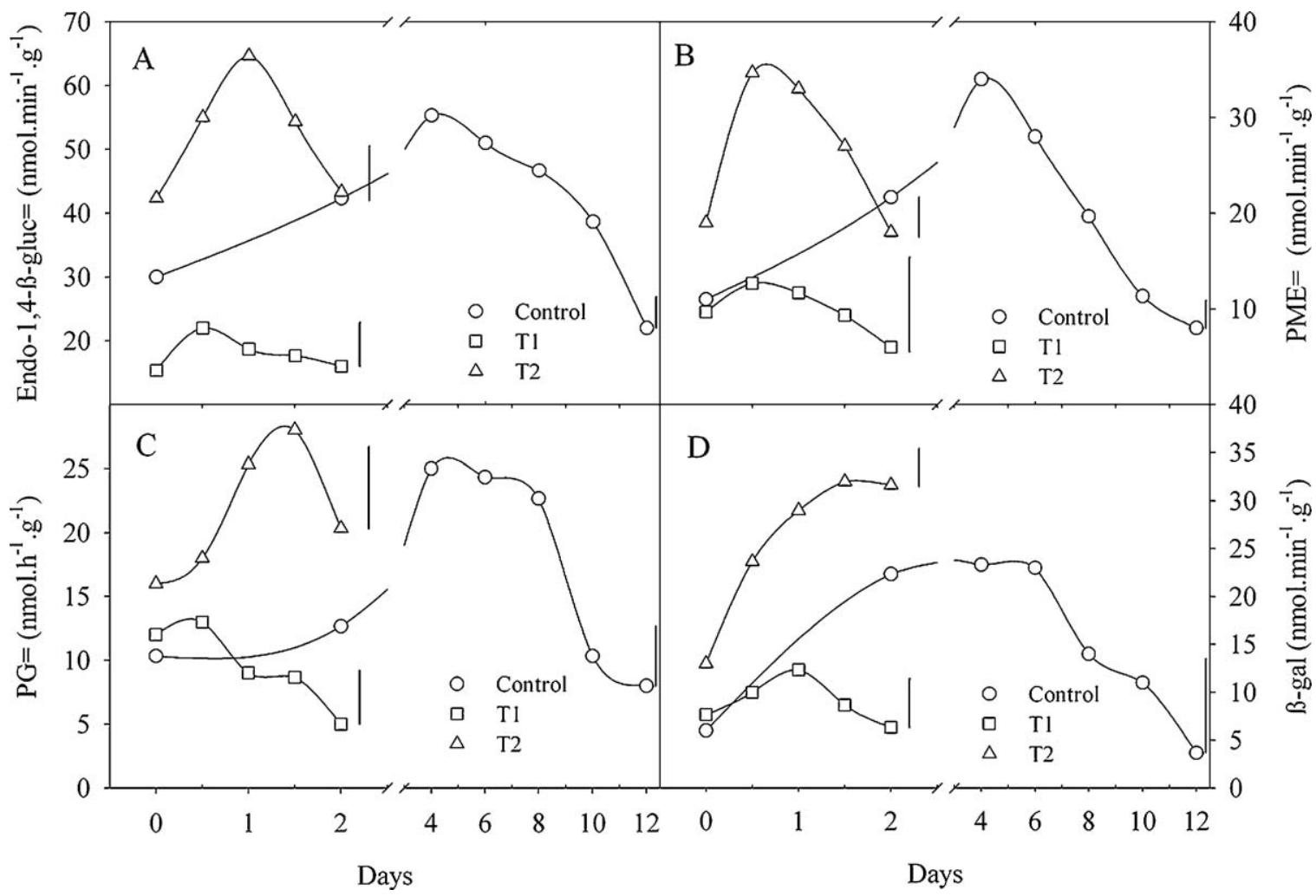

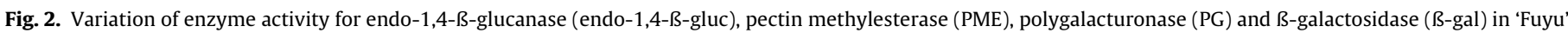

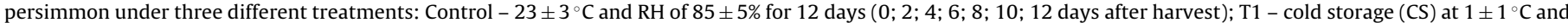

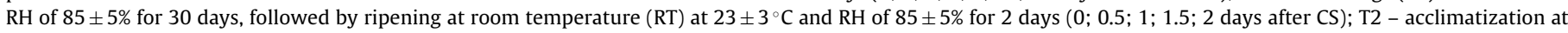

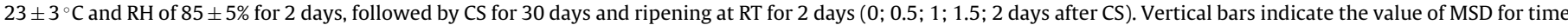
effect in each treatment $(p<0.05)$.

as observed in other fruit (George et al., 1997; Goulão and Oliveira, 2008).

The lower enzymatic activities and ethylene production in the T1 fruit suggest that the softening of the fruit was caused by the cold. Moreover, we observed that the fruit under T1 had internal structure damage including oxidation beginning on the second day after leaving the cold conditions (data not presented).

The increases in activity of the enzyme endo- $1,4-\beta$-gluc and the reductions in the FF during fruit ripening in the Control and

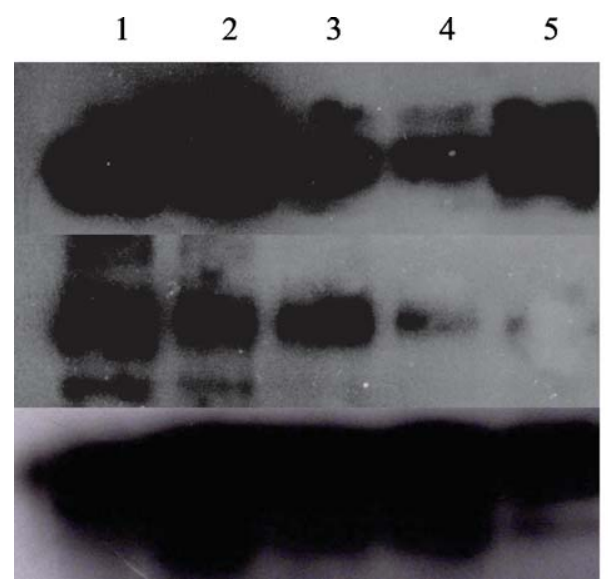

\section{Control}

Fig. 3. Immunodetection of expansins in 'Fuyu' persimmons during ripening at room temperature (Control) (1: harvest; $2: 2 ; 3: 6 ; 4: 8 ; 5: 10$ days), after cold storage (T1) (1: removal from cold chamber; $2: 0.5 ; 3: 1 ; 4: 1.5 ; 5: 2$ days) and after acclimatization followed by CS (T2), ( 1 : removal from cold chamber; $2: 0.5 ; 3: 1 ; 4$ : $1.5 ; 5: 2$ days)
T2 fruit was not found in previous studies of the depolymerization of xyloglucans in persimmons. In studies of strawberries and tomatoes, it was noted that endoglucanases are critical for fruit softening, and that the expression of their respective genes and proteins occurs incrementally during ripening (Brummell, 2006; Martínez and Civello, 2008).

PMEs and PGs enzymes are known to be necessary for cell division and expansion. Their activities are known to increase during ripening of the fruit, and each isoform has a specific contribution to this process. For example, even though transgenic tomato plants had lower activities of PME and PG, they still experienced a loss of firmness of their flesh (Tieman et al., 1992). Pech et al. (2008) characterized the ethylene-dependence of PGs as well as the genes involved in the process of melon ripening. In this study, because the method of dose of enzymatic activity was used, there was no way to discriminate between the isoforms of these proteins. In other words, this study only examined the apparent total activity, which consisted of both the enzyme potential to perform de-esterifications (PME) and hydrolysis (PG) of the polyuronide compounds of the cell wall.

According to Smith et al. (1998), as $\beta$-gal removes the galactosidase of the ramnogalacturanos chains, it reduces their ability to interact with other adjacent polysaccharides, which leads to increasing solubility and decreasing flesh firmness. This phenomenon has been previously shown in strawberries, in which the varieties of strawberries that had larger reductions in flesh firmness also demonstrated higher activities of $\beta$-gal and increased solubilization of the cell wall components (Goulão and Oliveira, 2008).

The higher accumulation of expansins in the fruit under Control and T2 is consistent with results from other studies (Brummell, 


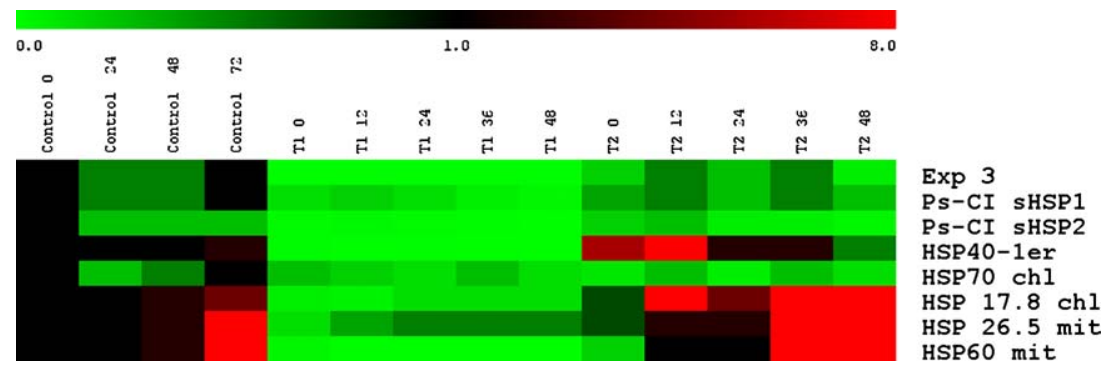

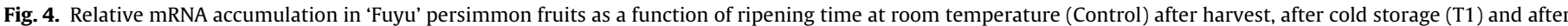

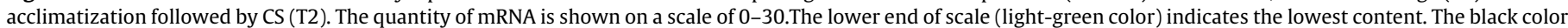

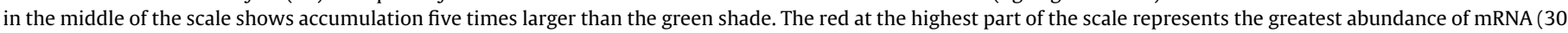
times higher than the lowest content). (For interpretation of the references to color in this figure legend, the reader is referred to the web version of this article.)

2006; Goulão and Oliveira, 2008). Because it is believed that expansins facilitate the breakage of the hydrogen bonds between cellulose, pectin and xyloglucans in cell walls, we would expect more action from the hydrolytic and de-esterifying enzymes in cells with higher content of expansins. In the case of the persimmons exposed to T1, softening could have been the consequence of the susceptibility of the fruit of persimmons 'Fuyu' to low temperatures in general, as suggested by other studies (Örvar et al., 2000). For each species, variety and organ, there is a combination of binomial time and temperature for which there is an associated increase in the content proteins involved in cold tolerance such as LEAs (late embryogenesis accumulated proteins), HSPs and molecules such sorbitol (Ferri et al., 2008).

The higher accumulation of cytosolic HSPs transcripts, endoplasmic reticulum, chloroplast and mitochondria in persimmons submitted to acclimatization (T2), suggests that acclimatization can stimulate genes that increase the fruit' cold tolerances at low temperatures by maintaining the integrity of the cellular organelles (Barsan et al., 2010), the cytoskeleton (Örvar et al., 2000) and the endomembrane system (Pegoraro et al., 2010).

The expansin studied here (Exp3) has signal peptides for transport via the endomembrane system, as predicted using iPSORT (Bannai et al., 2002). The fact that there was less transcript accumulation (Fig. 4) and a lower intensity of immune reactions after exposure to CS indicates that either the synthesis or transport of the expansins was affected by CS. Others causes could explain this fact. For example, a reduction in protein translation and/or acceleration in protein degradation are plausible alternative explanations. However, our hypothesis is most probable because the enzymes studied here as well as the expansions are proteins transport via the canonical system, which includes the endoplasmic reticulum and Golgi apparatus, although, this hypothesis needs to be further explored. Moreover, as there was greater expression of HSPs in the endoplasmic reticulum, in the chloroplasts and in the mitochondria in fruit kept under Control and under T2 conditions, it is likely that these conditions allow for better cell homeostasis. This improved homeostasis could explain the improved evolution of the process of ripening in these fruit.

In conclusion, the drastic softening of fruit after CS (T1) may be the result of physical damage caused by low temperatures. This problem can be attenuated through the use of acclimatization of persimmons at $23 \pm 3{ }^{\circ} \mathrm{C}$ for 2 days prior to CS (T1). This acclimatization stimulates greater accumulation of the transcripts corresponding to putative genes encoding cytosolic, mitochondrial, chloroplastic, endomembrane HSPs proteins; as well as proteins corresponding to expansins and enzymes that are involved in the cell wall disassembling. Together, the increased transcript production and protein production result in the adequate evolution of fruit ripening after CS. Furthermore, from a basic science point of view, our study highlights the involvement of HSPs in cold tolerance of fruit.

\section{Acknowledgments}

The authors acknowledge the CNPq and CAPES for scholarships and financial support.

\section{References}

Bannai, H., Tamada, Y., Maruyama, O., Nakai, K., Miyano, S., 2002. Extensive feature detection of N-terminal protein sorting signals. Bioinformatics 18, 298-305.

Barata-Soares, A.D., Gomez, M.L.P.A., Mesquita, C.H.D., Lajolo, F.M., 2004. Ascorbic acid biosynthesis: a precursor study on plants. Braz. J. Plant Physiol. 16, 147-154

Barsan, C., Sanchez-Bel, P., Rombaldi, C., Egea, I., Rossignol, M., Kuntz, M., Zouine, M., Latche, A., Bouzayen, M., Pech, J.C., 2010. Characteristics of the tomato chromoplast revealed by proteomic analysis. J. Exp. Bot. 61, 2413-2431.

Benson, D.A., Karsch-Mizrachi, I., Lipman, D.J., Ostell, J., Wheeler, D.L., 2005. GenBank. Nucleic Acids Res. 33, D34-D38.

Boston, R.S., Viitanen, P.V., Vierling, E., 1996. Molecular chaperones and protein folding in plants. Plant Mol. Biol. 32, 191-222.

Brummell, D.A., 2006. Cell wall disassembly in ripening fruit. Funct. Plant Biol. 33, 103-119.

Deacon, J., 2009. Yeast and yeast like-fungi: Saccharomyces, Cryptococcus and Candida albicans. The University of Edinburgh

Ferri, V.C., Rombaldi, C.V., Silva, J.A., Pegoraro, C., Nora, L., Antunes, P.L., Girardi, C.L., Tibola, C.S., 2008. Boron and calcium sprayed on 'Fuyu' persimmon tree prevent skin cracks, groove and browning of fruit during cold storage. Ciência Rural 38, 2146-2150.

George, A.P., Mowat, A.D., Collins, R.J., 1997. Factors affecting blemishing of persimmon in New Zealand and Australia. Acta Hort. 436, 171-178.

Girardi, C.L., Corrent, A.R., Lucchetta, L., Zanuzo, M.R., da Costa, T.S., Brackmann, A. Twyman, R.M., Nora, F.R., Nora, L., Silva, J.A., Rombaldi, C.V., 2005. Effect of ethylene, intermittent warming and controlled atmosphere on postharvest quality and the occurrence of woolliness in peach (Prunus persica cv. Chiripá) during cold storage. Postharvest Biol. Technol. 38, 25-33.

Gomez, M.L.P., Lajolo, F.M., 2008. Ascorbic acid metabolism in fruits: activity of enzymes involved in synthesis and degradation during ripening in mango and guava. J. Sci. Food Agric. 88, 756-762.

González-Agüero, M., Pavez, L., Ibanez, F., Pacheco, I., Campos-Vargas, R., Meisel, L.A., Orellana, A., Retamales, J., Silva, H., Gonzalez, M., Cambiazo, V., 2008. Identification of woolliness response genes in peach fruit after post-harvest treatments. J. Exp. Bot. 59, 1973-1986.

Goulão, L.F., Oliveira, C.M., 2008. Cell wall modifications during fruit ripening: when a fruit is not the fruit. Trends Food Sci. Technol. 19, 4-25.

Invitrogen, 2005. Vector NTI Advance ${ }^{\mathrm{TM}} 10$ Quick Start Guide. Invitrogen Corporation, Carlsbad.

Iwata, Y., Fedoroff, N.V., Koizumi, N., 2008. Arabidopsis bZIP60 is a proteolysisactivated transcription factor involved in the endoplasmic reticulum stress response. Plant Cell 20, 3107-3121.

Krammes, J.G., Argenta, L.C., Vieira, M.J., 2006. Influences of 1-methylcyclopropene on quality of persimmon fruit cv. 'Fuyu' after cold storage. In: Webster, A.D., Ramirez, H. (Eds.), X International Symposium on Plant Bioregulators in Fruit Production Acta Hort. (ISHS). Saltillo, Mexico, pp. 513-518.

Livak, K.J., Schmittgen, T.D., 2001. Analysis of relative gene expression data using real-time quantitative PCR and the 2(T)(-Delta Delta C) method. Methods 25 402-408.

Machado, A.A., Conceição, A.R., 2003. Sistema de análise estatística para Windows (Winstat), 2.0 ed. UFPel, Pelotas.

MacRae, E.A., 1987. Development of chilling injury in New Zealand grown Fuyu persimmon during storage. N. Z. J. Exp. Agr. 15, 333-344.

Martínez, G.A., Civello, P.M., 2008. Effect of heat treatments on gene expression and enzyme activities associated to cell wall degradation in strawberry fruit. Postharvest Biol. Technol. 49, 38-45.

Mueller, S., Hilbert, B., Dueckershoff, K., Roitsch, T., Krischke, M., Mueller, M.J., Berger, S., 2008. General detoxification and stress responses are mediated by oxidized lipids through TGA transcription factors in Arabidopsis. Plant Cell 20, 768-785. 
Nakamura, A., Maeda, H., Mizuno, M., Koshi, Y., Nagamatsu, Y., 2003. Betagalactosidase and its significance in ripening of "Saijyo" Japanese Persimmon fruit. Biosci. Biotechnol. Biochem. 67, 68-76.

Nakano, R., Ogura, E., Kubo, Y., Inaba, A., 2003. Ethylene biosynthesis in detached young persimmon fruit is initiated in calyx and modulated by water loss from the fruit. Plant Physiol. 131, 276-286.

Örvar, B.L., Sangwan, V., Omann, F., Dhindsa, R.S., 2000. Early steps in cold sensing by plant cells: the role of actin cytoskeleton and membrane fluidity. Plant J. 23, 785-794.

Pech, J.C., Bouzayen, M., Latché, A., 2008. Climacteric fruit ripening: ethylenedependent and independent regulation of ripening pathways in melon fruit. Plant Sci. 175, 114-120.

Pegoraro, C., Zanuzo, M.R., Chaves, F.C., Brackmann, A., Girardi, C.L., Lucchetta, L., Nora, L., Silva, J.A., Rombaldi, C.V., 2010. Physiological and molecular changes associated with prevention of woolliness in peach following pre-harvest application of gibberellic acid. Postharvest Biol. Technol. 57, $19-26$.

Pratt, W.B., Toft, D.O., 2003. Regulation of signaling protein function and trafficking by the hsp90/hsp70-based chaperone machinery. Exp. Biol. Med. 228, 111133.

Rose, J.K.C., Hadfield, K.A., Labavitch, J.M., Bennett, A.B., 1998. Temporal sequence of cell wall disassembly in rapidly ripening melon fruit. Plant Physiol. 117, 345-361.

Sabehat, A., Lurie, S., Weiss, D., 1998. Expression of small heat-shock proteins at low temperatures. A possible role in protecting against chilling injuries. Plant Physiol. 117, 651-658.
Saeed, A.I., Sharov, V., White, J., Li, J., Liang, W., Bhagabati, N., Braisted, J., Klapa, M., Currier, T., Thiagarajan, M., Sturn, A., Snuffin, M., Rezantsev, A., Popov, D., Ryltsov, A., Kostukovich, E., Borisovsky, I., Liu, Z., Vinsavich, A., Trush, V., Quackenbush J., 2003. TM4: a free, open-source system for microarray data management and analysis. Biotechniques 34, 374-378.

Smith, D.L., Starrett, D.A., Gross, K.C., 1998. A gene coding for tomato fruit betagalactosidase II is expressed during fruit ripening, cloning, characterization, and expression pattern. Plant Physiol. 117, 417-423.

Su, P.H., Li, H.M., 2008. Arabidopsis stromal 70-kD heat shock proteins are essential for plant development and important for thermotolerance of germinating seeds. Plant Physiol. 146, 1231-1241.

Sun, J.-H., Chen, J.-Y., Kuanga, J.-F., Chena, W.-X., Lu, W.-J., 2010. Expression of sHSP genes as affected by heat shock and cold acclimation in relation to chilling tolerance in plum fruit. Postharvest Biol. Technol. 55, 91-96.

Tieman, D.M., Harriman, R.W., Ramamohan, G., Handa, A.K., 1992. An antisense pectin methylesterase gene alters pectin chemistry and soluble solids in tomato fruit. Plant Cell 4, 667-679.

Trainotti, L., Bonghi, C., Ziliotto, F., Zanin, D., Rasori, A., Casadoro, G., Ramina, A Tonutti, P., 2006. The use of microarray mu PEACH1.0 to investigate transcriptome changes during transition from pre-climacteric to climacteric phase in peach fruit. Plant Sci. 170, 606-613.

Trainotti, L., Zanin, D., Casadoro, G., 2003. A cell wall-oriented genomic approach reveals a new and unexpected complexity of the softening in peaches. J. Exp. Bot. 54, 1821-1832.

Vinci, G., Botrè, F., Mele, G., Ruggieri, G., 1995. Ascorbic acid in exotic fruits: a liquid chromatographic investigation. Food Chem. 53, 211-214. 